\title{
Morphological Identification of Mycorrhizal Fungi Isolated from Native Orchid in Indonesia
}

\author{
Mahfut $^{*}$ \\ Department of Biology, Faculty of Mathematics and Natural Sciences, Universitas Lampung, Indonesia
}

Received: February 27, 2021; Revised: May 2, 2021; Accepted: November 28, 2021

\begin{abstract}
Moth orchid [Phalaenopsis amabilis (L.) Blume] is a species of native orchid from Indonesia. The association of this orchid with mycorrhizal fungi in nature is as a biocontrol agent. In a previous study, one Ceratobasidium isolate from Yogyakarta, Indonesia was successfully identified based on rDNA-ITS molecular analysis. This study aimed to identify these isolates based on morphological analysis to complement other identification data, namely anatomy and molecular. Verification morphological analysis is carried out by observing macroscopic and microscopic characteristics, as well as observing peloton. The results of showed that the characterization of Yogyakarta isolates had similarities with Ceratobasidium. These character equations include colony color, cell length, core number, and cell width. The examination of orchid roots also showed the presence of pelotons in the cortical cells. This study confirms that the fungal isolates of orchid mycorrhiza from Yogyakarta, Indonesia were Ceratobasidium based on morphological and molecular analysis. This research is one of the efforts to preserve native orchids in Indonesia using myccorhiza fungi as a biocontrol agent. This study is the first to report regarding Ceratobasidium isolated from native orchids in Indonesia based on morphological analysis.
\end{abstract}

Keywords: Ceratobasidium; mycorrhiza; morphological analysis; Phalaenopsis; Indonesia

\section{Introduction}

Orchid is a type of ornamental plant that has a high aesthetic value and is most in demand by the community (Mose et al., 2020). The moth orchid [Phalaenopsis amabilis (L.) Blume] is one of Indonesia's national flowers, namely the charm that was set through Presidential Indonesia Decree Number 4/1993. Diseases are still the main obstacle in the cultivation and development of natural orchids (Mahfut et al., 2019; Mahfut, 2020; Mahfut et al., 2020'b Mahfut et al., 2021).

Endophytic mycorrhiza is a form of symbiosis between fungi and plant roots during a certain period of their life cycle, forming colonies in plant tissues without endangering their hosts. In general, mycorrhizal fungi help germination of orchid seeds in the presence of ethylene and various vitamins. Another role is to support efforts to provide nutrition for plant growth and development (Haro and Benito, 2019), and to assist in the formation of more buds and flowers. In plant resistance, mycorrhiza fungi serve as a biological agent of control in plant protection against pathogenic infections (Safarini et al., 2020; Song et al., 2020).

In a previous study, Mahfut et al. (2020) reported one Ceratobasidium isolate from Yogyakarta, Indonesia based on rDNA-ITS molecular analysis. The results show sequences measuring 600-750 bp DNA products located on the ITS1-5.8S-ITS4 region. Reconstruction of phylogenetic trees resulted in Indonesian isolates having undergone speciation and separated from Ceratobasidium isolates from other countries. This research is a follow-up study which aims to clarify the identification of these isolates as Ceratobasidium based on morphological analysis. Furthermore, this research can be used as a benchmark in developing strategy for conserving moth orchid through protection against plant diseases.

\section{Materials and Methods}

\subsection{Collection of Healthy Orchid Root Samples and Endophytic Mycorrhizal Isolation}

Healthy root of $P$. amabilis collected from Yogyakarta, Indonesia on coordinates $8^{\circ} 30^{\prime}-7^{\circ} 20^{\prime}$ LS $109^{\circ} 40^{\prime}-111^{\circ}$ $0^{\prime}$ BT. The sample was taken to the Biotechnology Laboratory of the Faculty of Biology UGM to isolate endophytic mycorrhiza following the Chand et al. (2020) method. Isolation of endophytic fungi was then carried out by cutting the roots and culturing on PDA medium. The fungal colonies obtained from the isolation were then purified by sub-culturing aseptically and incubating for 7 days at room temperature $\left(20-25^{\circ} \mathrm{C}\right)$. It is possible that the isolates obtained are pure and single isolates that are not contaminated by other fungi.

\subsection{Macroscopic Characteristic Observation}

To observe the macroscopic characteristics of the isolated fungi, small portion of isolates $\left( \pm 1 \mathrm{~mm}^{2}\right)$ were placed in the middle of the PDA medium. Furthermore, the growth of the isolates was observed and measured every day for 7 days. Furthermore, observations of colony morphological characteristics such as colony color, colony

\footnotetext{
*Corresponding author e-mail: mahfut.mipa@fmipa.unila.ac.id.
} 
base color, the surface color of young colonies, the appearance of colonies, and the growth rate of the colony were carried out.

\subsection{Making Slide Culture Preparations}

Observation of microscopic characteristics was also carried out using the slide culture method (Stoian et al. 2019) with a slight modification. This method was carried out to monitor microscopic characteristics such as the color of hyphae, bulk in hyphae, angle of branching of hyphae, and number of cell nuclei. The number of nuclei was observed after treating with safranin and $3 \% \mathrm{KOH}$.

\subsection{Observation of Pelotons in roots}

Observation of peloton was carried out by making squash preparations on root samples which had been treated with previous endophytic fungal inoculations. Root samples are sliced and soaked in trypan blue dye for 15 minutes. Observations were carried out using a light microscope at $100 \mathrm{x}$ magnification.

\section{Results}

\subsection{Collection of Healthy Orchid Root Samples and Endophytic Mycorrhizal Isolation}

One endophytic fungus, namely Yogyakarta was isolated from root samples of $P$. amabilis in Yogyakarta, Indonesia in Figure 1.
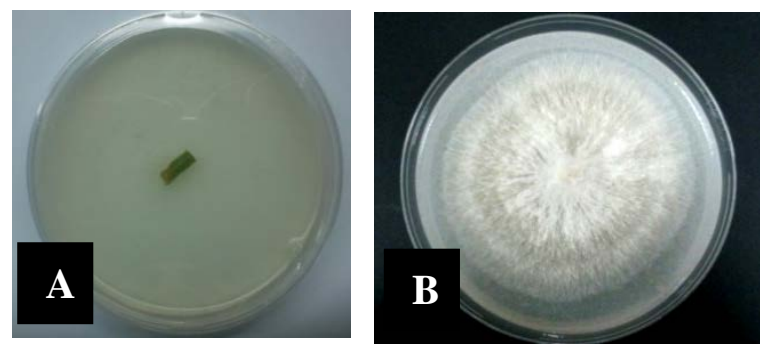

Figure 1. A) Root samples of MP1 cultured on PDA medium, B) Colonies of fungi that grow on 7 days old orchid roots

Identification results based on macroscopic, microscopic, and molecular characteristics showed that the isolate was Ceratorhiza which is one of the types of Rhizoctonia endophytic mycorrhiza. According to Chand et al. (2020), Ceratorhiza is Rhizoctonia grouped by cell hyphae and moniloid, and many are found to be associated with orchid roots.

\subsection{Macroscopic Characteristics}

Special characteristics of Yogyakarta isolate were identified as having branching types that formed elbows or $90^{\circ}$ angles and hyphae cells with a cell nucleus 2 (binucleate). These two characteristics are special characteristics of endophytic mycorrhiza. Endophytic fungi have 1-3 nuclei (binucleate) nuclei, whereas pathogenic fungi have more than 3 nuclei (multinucleates). This is in accordance with the opinion of Pannecoucque \& Hofie (2009) that in addition to binucleates, the characteristics of endophytic fungi are branching which forms a $90^{\circ} \mathrm{C}$ or $\mathrm{T}$-shaped branches.

Overall, the results of identification of Yogyakarta isolates showed similarities with the types of Ceratorhiza mycorrhiza. The following characteristics of Yogyakarta isolates compared to supporting references are presented in Tables 1 and 2.
Table 1. Comparison of the characteristics of Yogyakarta isolates and Cerathoriza isolates according to Shan et al. (2002)

\begin{tabular}{|c|c|c|}
\hline Characteristics & $\begin{array}{l}\text { Yogyakarta } \\
\text { Isolate }\end{array}$ & Cerathoriza Isolate \\
\hline $\begin{array}{l}\text { The surface color of } \\
\text { young colonies }\end{array}$ & $\begin{array}{l}\text { White to } \\
\text { yellow }\end{array}$ & Yellow to white \\
\hline $\begin{array}{l}\text { The appearance of } \\
\text { colonies }\end{array}$ & Like cotton & Like cotton \\
\hline Hyphae color & Hyaline & Hyaline \\
\hline Hyphae diameter $(\mu \mathrm{m})$ & $6.20-6.72$ & $3.8-7.5$ \\
\hline Monilioid cell form & $\begin{array}{l}\text { Elongated, } \\
\text { barrel shaped }\end{array}$ & $\begin{array}{l}\text { Ellipsoidal or } \\
\text { elongate barrel shape }\end{array}$ \\
\hline Monilioid cell size $(\mu \mathrm{m})$ & $\begin{array}{l}(12.22-14.56) \times \\
(2.39-2.91)\end{array}$ & $\begin{array}{l}(7.5-15.0) \times(10.0- \\
25.0)\end{array}$ \\
\hline $\begin{array}{l}\text { The growth rate of the } \\
\text { colony }(\mathrm{mm} / \mathrm{hr})\end{array}$ & 0.72 & $0.42-0.52$ \\
\hline Number of cell nuclei & Binucleate & Binucleate \\
\hline
\end{tabular}

Table 2. Comparison of the characteristics of Yogyakarta isolate and Cerathoriza isolates according to Currah and Zelmer (1992)

\begin{tabular}{|c|c|c|}
\hline Characteristics & $\begin{array}{l}\text { Yogyakarta } \\
\text { Isolate }\end{array}$ & $\begin{array}{l}\text { Cerathoriza } \\
\text { Isolate }\end{array}$ \\
\hline Colony color & White to yellow & $\begin{array}{l}\text { Cream, yellow, } \\
\text { or brown }\end{array}$ \\
\hline The appearance of colonies & Like cotton & Like cotton \\
\hline $\begin{array}{l}\text { The form of branching } \\
\text { hyphae }\end{array}$ & $90^{\circ}$ & $90^{\circ}$ \\
\hline Air hyphae diameter & $<3 \mu \mathrm{m}$ & $<4 \mu \mathrm{m}$ \\
\hline Number of nuclei per cell & Binucleate & Binucleate \\
\hline Clamp connection & - & - \\
\hline Surface of the colony & Like cotton & Flat and waxy \\
\hline Monilioid cells & $\begin{array}{l}\text { Elongate barrel } \\
\text { shaped }\end{array}$ & - \\
\hline Monilioid cell length & $12.22-14.56$ & - \\
\hline Monilioid cell width & 2.39-2.91 & - \\
\hline
\end{tabular}

Based on observations of hyphae and cells using safranin $\mathrm{O}-\mathrm{KOH}$ dye (Figure 2), it was found that Yogyakarta isolates were endophytic fungi of Ceratorhiza with specific characteristics having branching types that form elbows or $90^{\circ}$ angles, the color of vegetative hyphae is hyaline, with diameters of 6.20-6.72 $\mu \mathrm{m}$, fungal colonies form cell monilioids with elongate barrel shape and monilioid size $(12,22-14,56) \mu \mathrm{m} \times(2.39-2.91) \mu \mathrm{m}$.

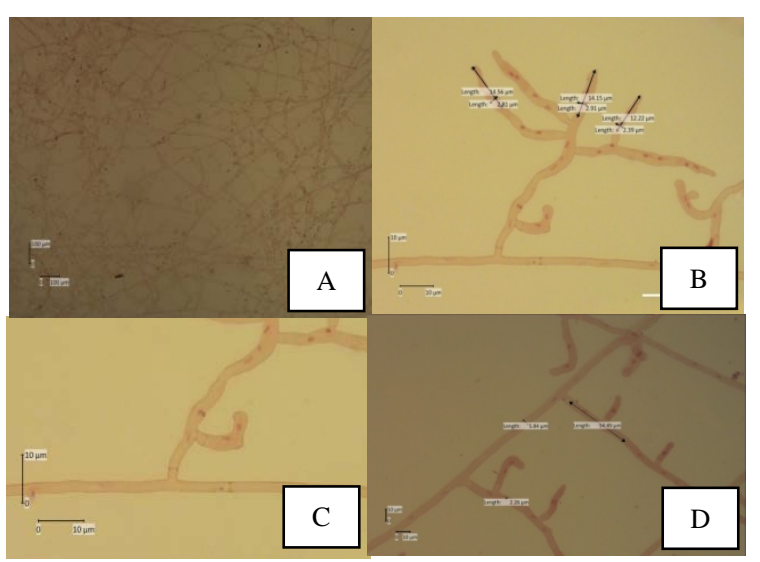

Figure 2. Microscopic observation of hyphae cells and moniliod cells Ceratorhiza from Yogyakarta isolates on the 7-day PDA medium using safranin $\mathrm{O}-\mathrm{KOH}$ staining; (A) Colony, (B) Monilioid cell nucleus, (C) Binucleate, (D) Branching of hyphae $90^{\circ}$. Magnification (A) $10 \mathrm{x},(\mathrm{B}, \mathrm{C}, \mathrm{D}) 40 \mathrm{x}$. Bar $=10 \mu \mathrm{m}$ 


\subsection{Observation of Endophytic Mycorrhizal Hyphae (Peloton)}

Observation of the cross section of the root sample indicated the presence of pelotons in the root cortex (Figure 3). Currah \& Zelmer (1992) explain that the characteristic of endophytic fungal hyphae colonizing plants will form a mass of dense hyphae in cortical cells called pelotons.

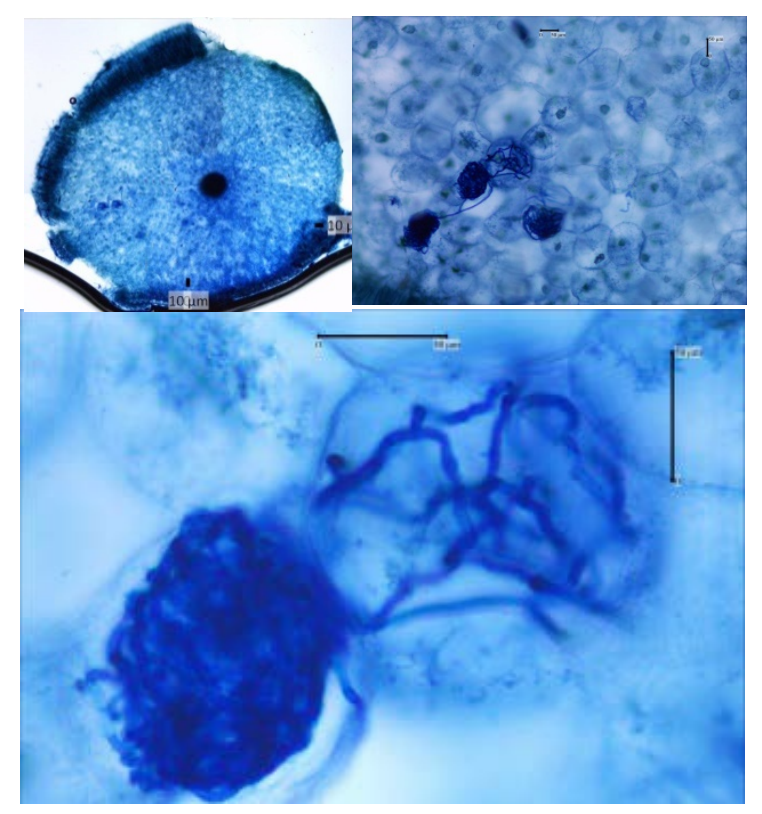

Figure 3. Peloton structure in the anatomy of the root cortex cells of MP1 with Tryphan Blue staining. Magnification (A) $4 \mathrm{x}$, (B) $10 \mathrm{x}$, (C) $40 \mathrm{x}$. Bar $=10 \mu \mathrm{m}$

\section{Discussion}

Characteristics of endophytic mycorrhizal analysis were obtained and compared with the reference characteristics (Shan et al., 2002; Currah and Zelmer, 1992); it was found that Yogyakarta isolates were Ceratorhiza isolates. Ceratorhiza is an anamorphic phase of Ceratobasidium. According to Athipunyakom et al. (2004), the genus Ceratorhiza is a mycorrhizal isolate which is commonly found associated with orchids, where endophytic fungi of this type are Rhizoctonia which are grouped according to cell hyphae and moniloid. Growth of Ceratorhiza reached a diameter of $9 \mathrm{~cm}$ after 4 days of incubation by forming a symmetrical zone. The colony turned yellowish after 7 days, and the colony surface appeared as cottony clumps. The lumps are aerial hyphae; this is known from the hyphae that grow on the surface of the agar media. These hyphae are fertile hyphae which play a role for reproduction. The length of moniloid cells is $12.22-14.56 \mu \mathrm{m}$, width $2.39-2.91 \mu \mathrm{m}$ and lancet-shaped. If the ratio of length and width is 3.5-4: 1 then it is called the lancet type. The number of nuclei in binucleic cells, according to the characteristics reported by Shan et al. (2002) and Currah and Zelmer (1992).

The peloton structure is evident in the roots of $P$. amabilis which are associated with endophytic fungi (Figure 3). One of the parameters for the mechanism of resistance induction can be the formation of a peloton structure which shows that endophytic fungi penetrate the epidermal finger and into the cortex. In the cortex, the pulp will enter the cell space (intracellular) and form a peloton.

The presence of peloton proves that the endophytic fungi can penetrate into the root tissue of $P$. amabilis. According to Currah and Zelmer (1992), the stage of infection with endophytic fungi begins with the formation of appressorium which is an inflated hyphae. These hyphae originate from spores that germinate or externally hyphae at the root surface of infected host plants. Hyphae will then penetrate the root surface mechanically and enzymatically into the space between the root epidermal cells and into the cortex and beyond. Hyphae develop without destroying the cells of the root cortex. In cortex cells, hyphae form a peloton in the form of dense hyphae. In the platoon, the accumulation of organic materials includes protein, glycogen, fat, and nutrients produced by absorption from the soil.

\section{Conclusion}

The results showed that the characterization of endophytic mycorrhizae from the roots of $P$. amabilis from Yogyakarta, Indonesia had similarities with the type of endophytic mycorrhizal Ceratorhiza. These character equations include colony surface color, colony appearance, hyphae color, hyphae diameter $(\mu \mathrm{m})$, cell monilioid shape, monilioid cell size $(\mu \mathrm{m})$, colony growth rate ( $\mathrm{mm} /$ hour), core number, hyphae branching shape, and clamp connection. The results of mycorrhizal induction also produce a peloton structure in orchid root cortex cells. The peloton structure is evident in the roots of $P$. amabilis which are associated with endophytic fungi. The presence of peloton proves that endophytic fungi can penetrate into the root tissue.

\section{References}

Chand K, Shah S, Sharma J, Paudel RM and Pant B. 2020. Isolation, characterization, and plant growth-promoting activities of endophytic fungi from a wild orchid Vanda cristata. Plant Sig Behavior, 15(5): 1744294.

Currah RS and Zelmer C. 1992. A Key and Notes for the Genera of Fungi Mycorrhizal with Orchids and A New Species in the Genus Epulorhiza. Rept Tottori Mycol Institution, 30: 43-59.

Haro R and Benito B. 2019. The Role of Soil Fungi in $\mathrm{K}^{+}$Plant Nutrition. Int J mol Sci, 20(13): 3169.

Mahfut. 2020. Identification and Detection Odontoglossum ringspot virus on Native Orchids Collection of Nurserys in Java, Indonesia. Proceeding of International Conference on Advanced Information Scientific Development (ICAISD). West Java, Indonesia. 1641: 1-8.

Mahfut, Anggreiny A, Wahyuningsih S, Handayani TT and Sukimin. $2020^{\mathrm{b}}$. Identification of Disease and Efforts to Protect Native Orchid Plants Against Bacteria Infection in Liwa Botanical Garden. Proceedings of ICAISD Conference. University of Bina Sarana Informatika. West Java, Indonesia.

Mahfut, Daryono BS, Indrianto A and Somowiyarjo S. 2019. Effectiveness Test of Orchid Mycorrhizal Isolate (Ceratorhiza and Trichoderma) Indonesia and Its Role as a Biofertilizer. Ann Res Review Biol, 33(4): 1-7. 
Mahfut, Indrianto A, Somowiyarjo S and Daryono BS 2020. Molecular phylogeny of orchids mycorrhiza isolated from native tropical orchids in Indonesia. Malaysian $J$ Microbiol, 16(1): 68-72.

Mahfut, Shafira H, Wahyuningsih S, Handayani TT and Sukimin. 2021. Identification of Virus Infection on Native Orchid in Liwa Botanical Garden. Proceedings of ICASMI Conference. University of Lampung. Lampung, Indonesia.

Mose W, Daryono BS, Indrianto A, Purwantoro A and Semiarti E. 2020. Direct Somatic Embryogenesis and Regeneration of an Indonesian orchid Phalaenopsis amabilis (L.) Blume under a Variety of Plant Growth Regulators, Light Regime, and Organic Substances. Jordan J Biol Sci. 13(4): 509-518.

Pannecoucque J and Hofie M. 2009. Interaction Between Cauliflower and Rhizoctonia Anastomosis Groups with Different Levels of Aggreeiveness. BMC Plant Biol, 9(95): 1-12.
Safarini M, Rosyidah IH, Mertaniasih NM, Hamzah MNSB, Novianti KA, Primaharinastiti R, Rahmawaty D and Isnaeni I. 2020. In vitro Antibacterial Activity of Cell Free Fermentation Supernatant of Passiflora edulis forma flavicarpa Sims. Fruit Fermented by de Man, Rogosa and Sharp Media. Jordan J Biol Sci. 13(4): 469-475.

Shan XC, Liew ECY, Weatherhead MA and Hodgkiss IJ. 2002. Characterization and Taxonomic Placement of Rhizoctonia-like Endophytes from Orchids Roots. Mycologia, 94(2): 230-239.

Song Z, Bi Y, Zhang J, Gong Y and Yang H. 2020. Arbuscular mycorrhizal fungi promote the growth of plants in the mining associated clay. Sci Reports, 10: 2663.

Stoian V, Vidican R, Crisan I, Puia C, Sandor M, Stoian VA, Pacurar F and Vaida I. 2019. Sensitive approach and future perspectives in microscopic patterns of mycorrhizal roots. Sci Reports, 9: 10233. 